\title{
PERENCANAAN PEMBELAJARAN BERBASIS MASJID DAN ALAM UNTUK PEMENUHAN PEMBENTUKAN KARAKTER PESERTA DIDIK
}

\author{
Annisa Widiarti \\ Nurul Ulfatin \\ Wildan Zulkarnain \\ Universitas Negeri Malang \\ annisawidi93@gmail.com
}

\begin{abstract}
This research was carried out with the aim to find out about the planning of mosque-based learning and nature in SD Saleh Malang and the obstacles that were passed in preparing mosque-based learning and nature. This research is a descriptive study using a qualitative research approach with case study research design. This research was conducted using interview techniques, documentation, and observation. Data analysis is done through data collection, data reduction, data presentation, and drawing conclusions and verification. The validity test of the data uses the criteria of degree of trust or credibility which includes triangulation, checking members (Member Checks), adequacy of reference materials, and increasing perseverance. The results of this study are: good learning planning in which mosque-based or natural-based learning is based on a curriculum in the form of a national curriculum, hidden curriculum, and family curriculum. After that the vision, the mission set by the school is also a reference in mosque-based learning and natural planning, and then followed by making syllabus in which contains five characters, making lesson plans that contain five characters, and licensing mosques or natural schools as learning facilities.
\end{abstract}

Keywords: planning learning, mosque-based learning and nature, character.

ABSTRAK: Penelitian ini dilaksanakan dengan tujuan untuk mengetahui tentang perencanaan pembelajaran berbasis masjid dan alam di SD Anak Saleh Malang dan hambatan yang dilalui dalam mempersiapkan pembelajaran berbasis masjid maupun alam. Penelitian ini merupakan penelitian deskriptif dengan menggunakan pendekatan penelitian kualitatif dengan desain penelitian studi kasus. Penelitian ini dilakukan dengan menggunakan teknik wawancara, dokumentasi, serta observasi. Analisis data dilakukan melalui koleksi data, reduksi data, penyajian data, serta penarikan kesimpulan dan verifikasi. Adapun uji keabsahan data menggunakan kriteria derajat kepercayaan atau kredebilitas yang meliputi triangulasi, pengecekan anggota (Member Checks), kecukupan bahan referensi, dan meningkatkan ketekunan. Hasil dari penelitian ini yaitu: perencanaan pembelajaran baik yang di dalamnya berbasis masjid atau pun alam, dilakukan dengan berpatokan pada kurikulum yang berupa kurikulum nasional, hidden curriculum, dan family curriculum. Setelah itu visi, misi yang telah ditetapkan oleh sekolah juga menjadi acuan dalam perencanaan pembelajaran berbasis masjid dan alam, dan kemudian dilanjutkan dengan pembuatan silabus yang di dalamnya berisi muatan panca karakter, pembuatan RPP yang berisi muatan panca karakter, serta perijinan masjid atau sekolah alam sebagai fasilitas belajar.

Kata Kunci: perencanaan pembelajaran, pembelajaran berbasis masjid dan alam, karakter.

Pada era sekarang ini karakter menjadi aspek penting yang perlu ditumbuhkembangkan kepada peserta didik untuk menjadikan mereka sosok manusia yang berkarakter. Karena manusia yang berkarakter baik dan kuat secara individual maupun sosial, adalah manusia yang memiliki moral, ahlak, dan budi 
pekerti yang baik. Seperti yang dikemukakan oleh Zubaedi (2011: 1) bahwa manusia yang hidup tanpa karakter adalah manusia yang membinatang. Untuk itu dengan adanya sekolah sebagai lembaga pendidikan, diharapkan dapat membantu mengembangkan karakter peserta didik agar menjadi pribadi yang lebih baik lagi. Pembelajaran yang berlangsung di sekolah menjadi hal penting yang perlu diperhatikan. Menurut Hanafy (2014: 74) pembelajaran adalah proses interaksi yang melibatkan komponen-komponen utama, yaitu peserta didik, pendidik, dan sumber belajar yang berlangsung dalam suatu lingkungan belajar. Namun, pada proses pembelajaran atau proses pendidikan saat ini di beberapa sekolah nyatanya masih lebih menekankan pembelajaran pada aspek otak kiri seperti hafalan dan hanya sekedar tahu saja. Hal itulah yang secara tidak langsung telah membunuh karakter peserta didik sehingga mereka menjadi tidak aktif dan kreatif.

Kegagalan sistem pendidikan di Indonesia saat ini merangsang tumbuhnya sekolah-sekolah alternatif yang diyakini memiliki mutu pendidikan lebih baik dari sekolah biasa. Salah satu sekolah alternatif yang sekarang ada yaitu sekolah dengan konsep pendidikan berbasis masjid dan alam. Pengintegrasian pembelajaran dengan masjid dan alam ini merupakan hal baru yang menjadi salah satu solusi dari kurang maksimalnya proses pembelajaran selama ini. Pada umumnya, kebanyakan masjid digunakan hanya sebagai tempat sembahyang dan peribadahan umat muslim saja. Bahkan terdapat beberapa masjid yang terkunci rapat di luar jam sholat. Tetapi sekarang ini untuk masjid yang terdapat di beberapa sekolah sudah digunakan sebagai fasilitas dan sumber belajar bagi peserta didik. Namun berbeda dengan alam yang sudah sejak lama digunakan oleh beberapa sekolah sebagai fasilitas dan sumber belajar.

Seperti hasil penelitian Desilia (2014) di Sekolah Dasar(SD)AlamAl-Ghifari Blitaryang menunjukan bahwa di sekolah tersebut memiliki alternatif pembelajaran, yaitu pembelajaran berbasis alam. Pada penelitian tersebut dijelaskan bahwa pembelajaran dilakukan diluar ruangan yaitu alam. SD Anak Saleh Malang merupakan lembaga pendidikan yang tidak hanya mengintegrasikan pembelajaran dengan alam namun juga mengintegrasikannya dengan masjid. Pada umumnya, suatu lembaga pendidikan hanya menggunakan salah satu hal tersebut saja sebagai fasilitas penunjang kegiatan pembelajaran.

Tujuan adanya masjid dan juga alam selain sebagai fasilitas penunjang kegiatan pembelajaran adalah sebagai penunjang pemenuhan pembentukkan karakter. SD Anak Saleh memiliki ciri khas karakter sendiri yang sering disebut dengan panca karakter anak saleh. Panca karakter anak saleh ini meliputi karakter kesalehan personal, kesalehan sosial, kesalehan kebangsaan, kesalehan kecendekiaan, dan kesalehan kealamiahan. Karakter-karakter ini lah yang menjadi tujuan utama dari segala kegiatan pembelajaran yang dilaksanakan di SD Anak Saleh. Jadi segala bentuk kegiatan harus bermuara pada pembentukkan panca karakter anak saleh. Oleh karena itu, kegiatan yang berkaitan dengan pembelajaran berbasis masjid maupun alam haruslah direncanakan dengan sebaik mungkin. Berdasarkan fakta dan pemikiran di atas, peneliti tertarik untuk meneliti tentang perencanaan pembelajaran berbasis masjid dan alam yang ada di SD Anak Saleh Malang dalam pemenuhan pembentukkan karakter peserta didik.

\section{METODE}

Penelitian ini merupakan penelitian deskriptif dengan menggunakan pendekatan penelitian kualitatif dengan menggunakan desain penelitian studi kasus. Alasan peneliti menggunakan pendekatan kualitatif yaitu untuk mengungkap secara deskriptif mengenai perencanaan pembelajaran berbasis masjid dan alam dalam pemenuhan pembentukkan karakter peserta didik. Ulfatin (2015: 46) menyatakan bahwa jenis penelitian studi kasus diartikan sebagai "suatu pendekatan dengan memusatkan perhatian pada suatu kasus tertentu secara intensif dan rinci". Artinya seorang peneliti harus melakukan pendalaman terhadap suatu kasus atau fenomena yang terjadi secara menyeluruh. Kehadiran peneliti di tempat lokasi pertama kali adalah untuk melakukan studi pendahuluan. Selain itu kehadiran peneliti selama dilapangan juga untuk mengumpulkan data. Total kehadiran peniliti ialah sebanyak 18 kali. Adapun tempat penelitian yang dilaksanakan ini di SD Anak Saleh Malang. Adapun alamat lengkapnya yaitu Jalan Arumba Nomor 31, Tunggulwulung, Kecamatan Lowokwaru, Kota Malang Provinsi Jawa Timur 65143. 
Pada sebuah penelitian, sumber data merupakan suatu hal penting. Sumber data dapat berupa seorang manusia maupun non manusia. Dalam penelitian ini sumber data yang berasal dari manusia yaitu kepala sekolah, wakil kepala sekolah bidang kurikulum atau akademik, wakil kepala sekolah bidang kesiswaan dan humas, guru mata pelajaran, guru tematik, serta koordinator alam, koordinator keislaman, wali murid, dan peserta didik. Sumber data yang bukan manusia yaitu rekaman hasil wawancara, dokumendokumen dan catatan lapangan (observasi).

Pengumpulan data dalam penelitian ini menggunakan teknik wawancara, dokumentasi dan observasi. Wawancara yang dilakukan ialah wawancara terstruktur dan tidak terstruktur. Dalam penelitian ini peneliti menggunakan teknik dokumentasi untuk memperkuat dan memperdalam informasi yang diperoleh melalui kegiatan wawancara dan observasi. Jenis pengamatan yang dilakukan oleh peneliti adalah pengamatan nonpartisipan. Pengamatan nonpartisipan yaitu peneliti tidak ikut aktif di dalam bagian kegiatan yang diamati (pengamat hanya mengamati dari jauh).

Data yang diperoleh kemudian diatur secara sistematis guna dianalisis. Nasution dalam Sugiyono (2012: 334) menyatakan bahwa dalam melakukan analisis memerlukan kerja keras karena analisis merupakan hal yang sulit. Adapun tahapan atau proses analisis data dilakukan sesuai dengan model atau siklus dari Miles, Huberman yaitu meliputi koleksi data, reduksi data, penyajian data, dan penggambaran kesimpulan serta verifikasi. Untuk pengecekan keabsahan hasil penelitian, peneliti menggunakan triangulasi, pengecekan anggota, kecukupan bahan referensi, serta meningkatkan ketekunan. Tahaptahap dalam penelitian ini yaitu dengan; 1) tahap persiapan; 2) tahap pendahuluan; 3) tahap penyusunan proposal skripsi; 4) tahap pelaksanaan; dan 5) tahap penyusunan laporan.

\section{HASIL}

\section{Profil Perencanaan Pembelajaran SD Anak Saleh Secara Umum}

Pengelolaan pembelajaran di SD Anak Saleh diawali dengan proses perencanaan. Perencanaan yang ada meliputi perencanaan kegiatan pembelajaran dan perencanaan program-program sekolah. Dalam penyusunannya, SD Anak Saleh selalu berkaca pada tujuan yang telah ditetapkan di visi sekolah. Visi sekolah yaitu mewujudkan pendidikan islami, berkualitas, kreatif dan inovatif, serta menghasilkan warga belajar beriman-bertaqwa-berahlak yang berperadaban dan ramah kehidupan berbasis panca karakter anak saleh. Untuk mencapai visi tersebut, maka diperlukanlah sebuah misi. Adapun misi sekolah yang telah ditetapkan yaitu; (a) menyediakan dan mengembangkan sumber daya pendidikan yang profesional; (b) menciptakan lingkungan belajar dan bermain yang menumbuhkan pembelajaran aktif, kreatif, efektif, menyenangkan, dan inovatif; (c) menumbuhkan nilai-nilai panca karakter anak saleh, yakni kesalehan personal, sosial, kebangsaan, kecendekiaan, dan kealamiahan pada setiap program dengan mendidik akal budi (fikir), mengasah hati nurani (dzikir), dan menerapkan amal shalih (fi'il); dan (d) memotivasi dan mencapai prestasi belajar dan kehidupan.

Kurikulum Nasional Tahun 2013 merupakan kurikulum yang digunakan oleh SD Anak Saleh sebagai patokan utama dalam menyusun segala kegiatan. Selain itu SD Anak Saleh juga mengintegrasikannya dengan beberapa kurikulum lain, yakni hidden curriculum dan family curriculum. Waktu pelaksanaan penyusunan pembelajaran di SD Anak Saleh selalu dilakukan di awal semester dengan didahului adanya workhsop. Kegiatan ini diikuti oleh beberapa unsur seperti guru, staf TU, kepala sekolah, wakil kepala sekolah, dan tim manajemen. Jika memungkinkan, sekolah juga akan mengajak orangtua atau komite untuk ikut kegiatan perencanaan pembelajaran.

\section{Perencanaan Pembelajaran Berbasis Masjid Untuk Pemenuhan Pembentukan Karakter Peserta Didik}

SD Anak Saleh Malang merupakan sebuah lembaga pendidikan yang didirikan oleh sebuah yayasan. Pembelajaran di SD Anak Saleh disetting dengan meliputi beberapa konsep. Terdapat empat konsep dalam sistem pembelajaran di SD Anak Saleh Malang, yakni pembelajaran masjid, kelas, IT, 
serta sekolah alam. Karena sistem pendidikan pada SD Anak Saleh ini lebih memadukan teori dan penerapannya, maka pembelajaran yang ada diintegrasikan dengan masjid. Sehingga pembelajaran yang ada dikatakan berbasis masjid. Pengintegrasian pembelajaran dengan masjid dilakukan oleh beberapa mata pelajaran. Selain mata pelajaran PAI, mata pelajaran lain seperti matematika, PJOK bahasa inggris dan tematik juga mengintegrasikan pembelajaran dengan masjid. Bentuk pengintegrasian mata pelajaran selain agama tersebut yaitu lebih sering ke edukasi dan juga pembiasaan. Untuk mata pelajaran PAI lebih sering ke prakteknya.

Jika dilihat dari kacamata anak saleh yang memiliki ciri khas panca karakter, maka muatan karakter yang ingin dididik oleh guru dalam pembelajaran berbasis masjid adalah condong kepada karakter sosial dan karakter personal. Sehingga muatan karakter pada silabus yaitu karakter personal dan juga karakter sosial. Hal tersebut juga sama dengan karakter yang termuat dalam RPP berbasis masjid. Sehingga muatan karakter pada RPP yaitu meliputi karakter personal seperti disiplin dan tanggung jawab, serta karakter sosial.

Setiap kegiatan pembelajaran berbasis masjid yang akan dilakukan di SD Anak Saleh selalu berpedoman pada visi misi. Penyusunan rencana pembelajaran berbasis masjid di SD Anak Saleh pada masing-masing mata pelajaran berbeda-beda. Dalam perencanaan pembelajaran tentunya selalu menyisipkan muatan karakter yang ingin dididik seperti yang tertera dalam visi misi SD Anak Saleh. Karakter yang ada di SD Anak Saleh digolongkan menjadi lima karakter yang biasa disebut dengan panca karakter anak saleh. Karakter tersebut meliputi karakter kesalehan personal, kesalehan sosial, kesalehan kebangsaan, kesalehan kecendekiaan, dan kesalehan kealamiahan. Untuk pedoman yang digunakan dalam menyusun rencana pembelajaran adalah kurikulum nasional 2013 yang diintegrasikan dengan hidden curriculum dan family curriculum. Tidak hanya itu saja, dalam perencanaannya para guru juga harus berkaca pada visi misi yang telah di tetapkan. Terdapat beberapa langkah yang dilalui dalam merencanakan kegiatan pembelajaran berbasis masjid. Langkah pertama dalam perencanaan tersebut ialah membuat silabus pembelajaran. Jika materi yang ada memiliki keterkaitan dengan pembelajaran berbasis masjid, maka di dalam silabus tersebut juga menyertakan kegiatan pembelajaran berbasis masjid. Selain itu dalam silabus juga menyisipkan panca karakter anak saleh sebagai muatan yang terkandung dalam pembelajaran yang akan dilakukan.

Kemudian langkah kedua adalah membuat RPP. Jika materi atau teori yang akan diajarkan memiliki keterkaitan dengan masjid, maka di dalam RPP tersebut juga bisa menyertakan kegiatan pembelajaran berbasis masjid. Selain itu dalam RPP juga menyisipkan panca karakter anak saleh sebagai muatan yang terkandung dalam pembelajaran yang akan dilakukan. Selanjutnya adalah langkah terakhir yakni mengurus perijinan penggunaan masjid sebagai fasilitas atau sumber belajar pada koordinator keislaman yang menaungi kegiatan masjid.

\section{Perencanaan Pembelajaran Berbasis Alam Untuk Pemenuhan Pembentukan Karakter Peserta Didik}

Sistem pendidikan pada SD Anak Saleh ini lebih memadukan teori dan penerapannya, untuk itu pembelajaran yang ada juga diintegrasikan dengan alam. Sehingga pembelajaran yang ada dikatakan berbasis alam. Alam di SD Anak Saleh ini merupakan laboratorium yang dapat memfasilitasi belajar anak. Namun tidak hanya itu, alam juga digunakan sebagai sumber atau resource oleh anak-anak. Sekolah alam yang dibangun di SD Anak Saleh Malang ini memiliki fasilitas yang baik dan lengkap, seperti area bermain, area perkebunan, area pertanian, area peternakan, area perikanan, dan gazebo. Pengintegrasian pembelajaran dengan alam di SD Anak Saleh ini hampir pada semua mata pelajaran. Mata pelajaran tersebut seperti mata pelajaran matematika, bahasa inggris, PJOK, tematik, dan PAI. Adapun karakter yang akan di bentuk dalam pembelajaran berbasis alam ialah karakter personal, sosial, dan juga karakter kealamiahan.

Muatan karakter pada pembelajaran berbasis alam di silabus rata-rata mencangkup karakter personal dan juga karakter sosial, dan juga karakter kealamiahan. Namun untuk RPP karakter yang termuat pada pembelajaran berbasis alam adalah lima karakter anak saleh. Karakter tersebut meliputi karakter 
personal, karakter sosial, karakter kebangsaan, karakter kecendekiaan, dan karakter keilmiahan. Pada RPP biasanya guru-guru melakukan pengembangan.

Setiap kegiatan pembelajaran berbasis alam yang akan dilakukan di SD Anak Saleh selalu berpedoman pada visi misi. Dalam perencanaan pembelajaran guru-guru selalu menyisipkan muatan karakter yang ingin didik seperti yang tertera dalam visi misi SD Anak Saleh. Karakter yang ada di SD Anak Saleh digolongkan menjadi lima karakter yang biasa disebut dengan panca karakter anak saleh. Karakter tersebut meliputi karakter kesalehan personal, kesalehan sosial, kesalehan kebangsaan, kesalehan kecendekiaan, dan kesalehan kealamihan. Untuk pedoman yang digunakan dalam menyusun rencana pembelajaran adalah Kurikulum Nasional 2013 dan diintegrasikan dengan hidden curriculum serta family curriculum. Tidak hanya itu saja, dalam perencanaannya para guru juga harus berkaca pada visi misi yangt telah di tetapkan. Langkah yang ditempuh dalam merencanakan pembelajaran berbasis alam ini pada dasarnya sama dengan langkah yang ditempuh dalam menyusun perencanaan pembelajaran berbasis masjid. Adapun langkah tersebut meliputi tiga langkah. Langkah pertama dalam perencanaan tersebut ialah membuat silabus pembelajaran. Jika materi yang ada memiliki keterkaitan dengan pembelajaran berbasis alam, maka di dalam silabus tersebut juga menyertakan kegiatan pembelajaran berbasis alam. Selain itu dalam silabus juga menyisipkan panca karakter anak saleh sebagai muatan dalam pembelajaran yang akan dilakukan. Kemudian langkah kedua adalah membuat RPP. Jika materi atau teori yang akan diajarkan memiliki keteraitan dengan alam, maka di dalam RPP tersebut juga bisa menyertakan kegiatan pembelajaran berbasis alam. Selain itu dalam RPP juga menyisipkan panca karakter anak saleh sebagai muatan dari pembelajaran yang akan dilakukan. Selanjutnya adalah langkah terakhir yakni mengurus perijinan penggunaan alam sebagai fasilitas atau sumber belajar pada koordinator sekolah alam.

\section{Hambatan Yang Dihadapi Dalam Mempersiapkan Pembelajaran Berbasis Masjid \& Alam Untuk Pemenuhan Pembentukan Karakter Peserta Didik}

Selama proses mempersiapkan pembelajaran baik pembelajaran berbasis masjid maupun pembelajaran berbasis alam tidak terlepas dari kemungkinan terjadinya suatu hambatan. Hal ini dialami oleh beberapa guru dan juga koordinator keislaman serta koordinator sekolah alam. Untuk hambatan yang dialami guru dalam mempersiapkan pembelajaran berbasis masjid, yaitu berupa kesulitan dalam mengaitkan materi pembelajaran dengan masjid. Selain hambatan tersebut, kesulitan lain yang dialami berupa kesulitan dalam mengatur waktu yang mungkin berbenturan dengan kegiatan lainnya. Sedangkan untuk hambatan yang dihadapi guru dalam mempersiapkan pembelajaran berbasis alam yaitu berupa cuaca yang bisa saja berubah sewaktu-waktu. Sehingga situasi dan kondisipun akan berubah karena adanya hambatan tersebut. Selain hambatan tersebut, juga ada hambatan lain yang dihadapi para guru dalam mempersiapkan pembelajaran berbasis alam seperti hambatan ketika tidak ada keterkaitan materi dengan alam, dan waktu integrasi dengan alam yang kurang pas.

Selain guru yang mengalami hambatan dalam mempersiapkan pembelajaran berbasis masjid maupun alam, koordinator keislaman pun juga mengalaminya. Adapun hambatan yang dihadapi dalam mempersiapkan pembelajaran berbasis masjid seperti hambatan yang berasal dari peserta didik, kemudian hambatan yang berasal dari guru, dan hambatan yang berasal dari fasilitas. Untuk hambatan yang berasal dari peserta didik seperti adanya seseorang anggota TTM yang tidak mampu bekerjasama dengan tim. Kemudian untuk hambatan yang berasal dari guru yakni seperti sulit berkoordinasi saat berbenturan waktu. Dan untuk hambatan yang berasal dari fasilitas, karena ada banyak fasilitas yang harus diadakan, maka harus bergantian untuk mendapatkannya.

Sedangkan untuk hambatan yang dihadapi oleh koordinator sekolah alam dalam mempersiapkan pembelajaran berbasis alam adalah kesulitan bertemu dengan teman-teman atau guru-guru untuk berdiskusi. Berikut ini bagan mengenai hambatan yang dihadapi baik guru, koordinator keislaman, dan koordinator sekolah alam dalam mempersiapkan pembelajaran. 


\section{PEMBAHASAN}

\section{Profil Perencanaan Pembelajaran SD Anak Saleh Secara Umum}

Setiap lembaga pendidikan, memiliki konsep yang berbeda-beda dalam menerapkan pembelajaran. SD Anak Saleh Malang adalah lembaga pendidikan yang mengintegrasikan pembelajaran dengan masjid dan alam untuk menunjang kegiatan belajar mengajar. Adanya pembelajaran yang berbasis masjid dan alam ini merupakan alternatif dari pendidikan yang diyakini memiliki mutu lebih baik lagi. Berhubungan dengan mutu pendidikan yang lebih baik, pemerintah juga sudah mengeluarkan peraturan yaitu Peraturan Presiden Republik Indonesia Nomor 87 Tahun 2017 tentang Pendidikan Penguatan Karakter (PPK). PPK dilaksanakan dengan menerapkan nilai-nilai pancasila dalam pendidikan karakter terutama meliputi nilai-nilai religius, jujur, toleran, disiplin, bekerja keras, kreatif mandiri, demokratis, rasa ingin tahu, semangat kebangsaan, cinta tanah air, menghargai prestasi, komunikatif, cinta damai, gemar membaca, peduli lingkungan, peduli sosial, dan bertanggungjawab. Dan berkaitan dengan hal tersebut, SD Anak Saleh juga memiliki visi yaitu terwujudnya pendidikan islami, berkualitas, kreatif dan inovatif, serta menghasilkan warga belajar beriman-bertaqwa-berahlak yang berperadaban dan ramah kehidupan berbasis panca karakter anak saleh. Panca karakter anak saleh ini terdiri dari kesalehan personal, kesalehan sosial, kesalehan kebangsaan, kesalehan kecendekiaan, dan kesalehan kealamiahan. Jadi dari awal SD Anak Saleh telah memiliki visi yang sejalan dengan pemerintah.

Visi sekolah akan tercapai jika segala kegiatan pembelajaran dikelola dengan baik. Oleh karena itu manajemen pembelajaran sangatlah penting. Manajemen dapat dikatakan sebagai hal penting yang perlu diperhatikan dalam suatu organisasi. Seperti yang dikemukakan oleh Rohman \& Amri (2015: 36) bahwa manajemen adalah kekuatan utama pada suatu organisasi dalam mengatur atau mengkoordinasikan kegiatan-kegiatan sub-sub sistem dan kemudian menghubungkannya dengan lingkungan. Artinya, jika suatu organisasi ingin tujuannya tercapai dengan baik, maka sudah seharusnya memahami dan menerapkan ilmu manajemen dengan baik dan benar. Manajemen pembelajaran di SD Anak Saleh Malang ini diawali dengan proses perencanaan. Perencanaan pembelajaran menurut Triwiyanto (2015: 97) adalah "seperangkat rencana dan pengaturan kegiatan pembelajaran, media pembelajaran, waktu, pengelolaan kelas, dan penilaian hasil belajar". Kegiatan pembelajaran berbasis masjid di SD Anak Saleh telah diatur oleh koordinator keislaman yang bertanggung jawab atas kegiatan yang ada di masjid. Begitu juga dengan kegiatan pembelajaran yang berbasis alam juga diatur oleh koordinator, yakni koordinator sekolah alam. Jadi masing-masing tempat baik di masjid ataupun sekolah alam, telah ditentukkan koordinator yang bertugas untuk mengatur segala kegiatan yang ada di tempat tersebut.

Perencanaan pembelajaran yang dilakukan oleh SD Anak Saleh setiap semesternya ini berpedoman pada kurikulum pemerintah, yaitu kurikulum 2013. Tidak hanya kurikulum 2013 saja, SD Anak Saleh ini juga mengintegrasikan dengan kurikulum lain seperti hidden curriculum, dan family curriculum. Untuk penyusunan perencanaan kegiatan pembelajaran, SD Anak Saleh selalu melakukan workhsop disetiap awal semester.

Pada kegiatan yang berkaitan dengan pembelajaran biasanya akan tercipta berbagai teknik yang bersifat kelembagaan, yang artinya disesuaikan dengan lembaga pendidikan tertentu. Adapun macammacam teknik tersebut menurut Pidarta dalam Rohman \& Amri (2015: 119) yaitu: (1) Teknik dalam menciptakan masyarakat belajar di sekolah; (2) Teknik dalam menciptakan masyarakat ilmiah di perguruan tinggi; (3) Teknik dalam mengadakan dan mengatur sumber belajar yang ada; (4) Teknik dalam meningkatkan partisipasi alumni dan masyarakat; (5) Teknik dalam meningkatkan kerja sama dengan lembaga-lembaga yang sejenis; dan (6) Teknik dalam ketatausahaan yang tepat waktu dan konsisten.

Berdasarkan pernyataan diatas. pembelajaran berbasis masjid dan sekolah alam yang ada di SD Anak Saleh termasuk dalam teknik dalam mengadakan dan mengatur sumber belajar yang ada, karena dalam hal ini SD Anak Saleh telah mengadakan masjid dan juga sekolah alam sebagai sumber belajar peserta didik untuk menunjang kegiatan pembelajaran. 


\section{Perencanaan Pembelajaran Berbasis Masjid Untuk Pemenuhan Pembentukkan Karakter Peserta Didik}

Masjid menurut Tihami dalam Setiyowati (2016: 27) adalah bangunan atau gedung atau suatu lingkungan yang ditembok untuk digunakan sebagai tempat menunaikan shalat, baik shalat lima waktu, maupun shalat Jum'at atau salat hari raya. Fungsi lain masjid selain untuk beribadah menurut Sutarmadi dalam Setiyowati (2016: 27) adalah sebagai fungsi sosial kemasyarakatan, sebagai fungsi pendidikan, dan sebagai fungsi ekonomi. Masjid di SD Anak Saleh selain untuk beribadah juga berfungsi sebagai sarana dalam menyelenggarakan pendidikan. Untuk itu dalam memanajemen masjid SD Anak Saleh memiliki caranya sendiri.

Fungsi manajemen yang pertama kali adalah fungsi perencanaan. Terkait dengan pengelolaan masjid, SD Anak Saleh selalu menjalankan fungsi manajemen yang pertama yakni perencanaan. Perencanaan menurut Usman (2014: 77) adalah "kegiatan yang akan dilakukan di masa yang akan datang untuk mencapai tujuan". Segala sesuatu yang akan dilakukan di SD Anak Saleh termasuk kegiatan pembelajaran berbasis masjid selalu direncanakan dengan baik guna mencapai tujuan yang telah ditetapkan dalam visi SD Anak Saleh.

Melalui pembelajaran berbasis masjid inilah peserta didik akan dibentuk karakternya. Terdapat beberapa jenis karakter yang sering dilaksanakan dalam proses pendidikan menurut Khan dalam Siswanto (2013: 98) yaitu: (1) Pendidikan karakter berbasis nilai religius; (2) Pendidikan karakter berbasis nilai budaya; (3) Pendidikan karakter berbasis lingkungan (konservasi lingkungan); dan (4) Pendidikan karakter berbasis potensi diri. Dari jenis karakter yang diutarakan diatas, pembelajaran berbasis masjid condong masuk ke dalam jenis karakter yang berbasis nilai religius. Jadi jika dilihat dari kacamata anak saleh yang memiliki ciri khas panca karakter, maka muatan karakter yang ingin dididik oleh guru dalam pembelajaran berbasis masjid adalah condong kepada karakter kesalehan personal dan kesalehan sosial.

Perencanaan pembelajaran dalam kurikulum biasa disebut dengan RPP. RPP merupakan Rencana yang disusun yang berisi tentang pelaksanaan pembelajaran yang akan dilakukan dengan mengacu pada silabus. Silabus yang dibuat oleh para guru di SD Anak Saleh berbentuk seperti pada umumnya. Namun tidak semua mata pelajaran mencantumkan kegiatan pembelajaran yang berbasis masjid dalam silabus. Begitu juga dengan RPP, tidak semua mata pelajaran mencantumkan kegiatan pembelajaran yang berbasis masjid pada RPP. Dalam hal ini menurut Triwiyanto (2015: 98) RPP mencangkup: (1) data sekolah, mata pelajaran, dan kelas/semester; (2) materi pokok; (3) alokasi waktu; (4) tujuan pembelajaran, kompetensi dasar dan indikator pencapaian kompetensi; (5) materi dan metode pembelajaran; (6) media, alat, dan sumber belajar; (7) langkah-langkah kegiatan pembelajaran; dan (8) penilaian. Begitu juga dengan SD Anak Saleh yang mencantumkan beberapa komponen tersebut dalam RPP.

Pengintegrasian pembelajaran dengan masjid dalam silabus atau RPP yang dibuat oleh guru, diawali dengan keterkaitan materi terlebih dahulu. Dalam hal ini, jika materi yang disampaikan sesuai maka barulah diintegrasikan dengan masjid. Kemudian Berkaitan dengan pengelolaan masjid di SD Anak Saleh, terdapat perijinan penggunaan tempat terlebih dahulu jika ingin menggunakan.

\section{Perencanaan Pembelajaran Berbasis Alam Untuk Pemenuhan Pembentukkan Karakter Peserta Didik}

Penyelenggarakan pendidikan menurut Mufidah (2015: 40) mencangkup beberapa hal seperti: (1) pembelajaran yang dilakukan harus dapat membentuk jiwa eksploratif pada peserta didik; (2) Kegiatan kreatif; dan (3) Kegiatan integral. Beberapa hal tersebut itu benar-benar bisa dilakukan ketika terdapat media pembelajaran yang sangat mendukung seperti di SD Anak Saleh yang memiliki sekolah alam. Sekolah alam yang ada di SD Anak Saleh Malang ini sering kali digunakan oleh beberapa guru mata pelajaran untuk fasilitas yang mendukung proses belajar peserta didik.

Pembelajaran dikatakan sebagai proses yang diselenggarakan oleh guru untuk membelajarkan siswa dalam belajar bagaimana belajar memperoleh dan memproses pengetahuan, keterampilan, dan sikap (Dimyati \& Mudjiono, 2009: 157). Berkaitan dengan hal tersebut, guru di SD Anak Saleh selalu 
melakukan upaya untuk memanage kegiatan pembelajaran dengan baik. Fungsi manajemen yang pertama kali adalah fungsi perencanaan. Terkait dengan pengelolaan kegiatan pembelajaran di sekolah alam, SD Anak Saleh selalu menjalankan fungsi manajemen yang pertama yakni perencanaan. Usman (2014: 77) menyatakan bahwa perencanaan adalah "kegiatan yang akan dilakukan di masa yang akan datang untuk mencapai tujuan". Sesuai dengan pernyataan tersebut, kegiatan pembelajaran yang dilakukan di SD Anak Saleh selalu direncanakan dan diarahkan untuk mencapai tujuan yang telah ditetapkan pada visi sekolah.

Ada beberapa hal yang semestinya diperhatikan dalam menciptakan pembelajaran agar siswa betul-betul menyenangi, menghayati, melaksanakan, dan terlibat dalam proses pelestarian alami (Mufidah,2015: 40). Hal tersebut meliputi: (1) Pembelajaran yang dilakukan harus dapat membentuk jiwa eksploratif pada peserta didik; (2) Kegiatan kreatif. Kegiatan kreatif merupakan sisi lain dari mata uang jiwa eksploratif; (3) Kegiatan integral. Kegiatan pembelajaran yang dilakukan di SD Anak Saleh ini selalu diarahkan kepada kegiatan seperti hal tersebut.

Terdapat beberapa jenis karakter yang sering dilaksanakan dalam proses pendidikan menurut Khan dalam Siswanto (2013: 98) yaitu: (1) Pendidikan karakter berbasis nilai religius; (2) Pendidikan karakter berbasis nilai budaya; (3) Pendidikan karakter berbasis lingkungan; dan (4) Pendidikan karakter berbasis potensi diri. Dari jenis karakter yang diutarakan tersebut, pembelajaran berbasis alam condong masuk ke dalam jenis karakter yang berbasis lingkungan. Beberapa karakter yang ingin dididik oleh guru dalam pembelajaran berbasis alam salah satunya adalah karkater kesalehan kealamiahan. Selain itu juga masih terdapat karakter kesalehan personal dan juga kesalehan sosial.

Pada perencanaan, silabus dan RPP yang dibuat oleh para guru di SD Anak Saleh berbentuk seperti pada umumnya. Hanya saja untuk penulisannya tidak semua mata pelajaran selalu mencantumkan alam sebagai sumber belajar di dalam silabus maupun RPP. Pengintegrasian pembelajaran dengan alam dalam silabus atau RPP yang dibuat oleh guru, diawali dengan keterkaitan materi terlebih dahulu. Dalam hal ini, jika materi yang disampaikan sesuai maka barulah diintegrasikan dengan alam. Atau jika tidak ketika pembelajaran di kelas terasa membosankan, biasanya sering dipindahkan ke sekolah alam untuk memperoleh suasana yang baru sehingga memungkinkan peserta didik lebih konsentrasi dan kreatif. Seperti pernyataan Santoso (2010: 12) adanya sekolah alam "dapat menjadi alternatif sekolah yang bisa membawa anak menjadi lebih kreatif, berani mengungkapkan keinginannya dan mengarahkan anak pada hal-hal yang positif.

\section{Hambatan Yang Dihadapi Dalam Mempersiapkan Pembelajaran Berbasis Masjid \& Alam Untuk Pemenuhan Pembentukkan Karakter Peserta Didik}

Setiap kegiatan tidak terlepas dari kemungkinan terjadinya suatu hambatan. Beberapa guru mata pelajaran di SD Anak Saleh mengalami hambatan seperti kesulitan dalam mengaitkan materi dengan masjid, dan kesulitan dalam mengatur waktu yang berbenturan dengan kegiatan lainnya. Kemudian untuk hambatan yang dihadapi oleh koordinator keislaman yaitu seperti hambatan yang berasal dari peserta didik, kemudian hambatan yang berasal dari guru, dan hambatan yang berasal dari fasilitas. Untuk hambatan yang berasal dari peserta didik seperti adanya seseorang anggota TTM yang tidak mampu bekerjasama dengan tim. Kemudian untuk hambatan yang berasal dari guru yakni seperti sulit berkoordinasi saat berbenturan waktu. Dan untuk hambatan yang berasal dari fasilitas, karena ada banyak fasilitas yang harus diadakan, maka harus bergantian untuk mendapatkannya.

Menurut Mufidah (2015: 41) adapun konsep penerapan pada sekolah alam adalah: (1) Determanis Resiprokal; (2) Tanpa Reinforcement; dan (3) Anak-anak memiliki jiwa ingin tahu terhadap lingkungan sekitar dan mengatur cara belajarnya sendiri. Melalui sekolah alam, siswa belajar tidak hanya mendengar penjelasan dari gurunya saja, tetapi juga dengan melihat, menyentuh, merasakan secara langsung dan mengikuti keseluruhan proses dari setiap pembelajaran. Namun dalam mempersiapkan pembelajaran berbasis alam tersebut, terdapat hambatan yang dihadapi baik oleh guru maupun koordinator sekolah alam di SD Anak Saleh. Hambatan yang dihadapi guru kebanyakan hambatan yang berupa cuaca berubah-ubah, tidak ada keterkaitan materi dengan alam, dan waktu integrasi dengan alam. Sedangkan 
untuk hambatan yang dihadapi oleh koordinator sekolah alam adalah kesulitan dalam bertemu dengan teman-teman atau guru-guru untuk diskusi.

\section{KESIMPULAN DAN SARAN}

SD Anak Saleh Malang adalah lembaga pendidikan yang mengintegrasikan pembelajaran dengan masjid dan juga alam, sehingga pembelajaran yang ada dikatakan berbasis masjid dan alam. Masjid dan alam di SD Anak Saleh ini merupakan laboratorium yang dapat memfasilitasi belajar anak. Segala kegiatan pembelajaran yang ada baik berbasis masjid maupun alam, dirancang dan disusun sesuai dengan kurikulum, visi dan misi sekolah yang telah ditetapkan. Kurikulum yang digunakan oleh SD Anak Saleh adalah kurikulum 2013 yang diintegrasikan dengan hidden curriculum dan family curriculum.

Kegiatan pembelajaran di SD Anak Saleh Malang ini diawali dengan proses perencanaan. Segala kegiatan maupun pembelajaran yang akan dilakukan tidak lepas dari target pencapaian karakter anak saleh. Perencanaan pembelajaran selalu dilakukan di awal semester dan didahului dengan workhsop terlebih dahulu. Adapun langkahnya yaitu membuat silabus pembelajaran. Jika materi yang ada memiliki keterkaitan dengan pembelajaran berbasis masjid maupun alam, maka di dalam silabus tersebut juga menyertakan kegiatan pembelajaran berbasis masjid maupun alam. Selain itu dalam silabus juga menyisipkan panca karakter anak saleh sebagai goal dari pembelajaran yang akan dilakukan. Kemudian langkah kedua adalah membuat RPP. Jika materi atau teori yang akan diajarkan memiliki keteraitan dengan masjid ataupun alam, maka di dalam RPP tersebut juga bisa menyertakan kegiatan pembelajaran berbasis masjid maupun alam. Selain itu sama dengan silabus, dalam RPP juga menyisipkan panca karakter anak saleh. Selanjutnya adalah langkah terakhir yakni mengurus perijinan penggunaan masjid maupun alam sebagai fasilitas atau sumber belajar pada koordinator masing-masing koordinator tempat tersebut.

Selama proses mempersiapkan pembelajaran baik pembelajaran berbasis masjid maupun pembelajaran berbasis alam mengalami beberapa hambatan. Untuk hambatan yang dialami guru dalam mempersiapkan pembelajaran berbasis masjid, yaitu berupa kesulitan dalam mengaitkan materi pembelajaran dengan masjid. Selain hambatan tersebut, kesulitan lain yang dialami berupa kesulitan dalam mengatur waktu yang mungkin berbenturan dengan kegiatan lainnya. Sedangkan untuk hambatan yang dihadapi guru dalam mempersiapkan pembelajaran berbasis alam yaitu berupa cuaca yang bisa saja berubah sewaktu-waktu. Selain tidak ada keterkaitan materi dengan alam, dan waktu integrasi dengan alam yang kurang pas juga menjadi sebuah hambatan. Selain guru yang mengalami hambatan dalam mempersiapkan pembelajaran berbasis masjid maupun alam, koordinator keislaman pun juga mengalaminya. Adapun hambatan yang dihadapi dalam mempersiapkan pembelajaran berbasis masjid seperti adanya seseorang anggota TTM yang tidak mampu bekerjasama dengan tim. Kemudian sulit berkoordinasi dengan guru saat berbenturan waktu. Dan hambatan karena ada banyak fasilitas yang harus diadakan, maka harus bergantian untuk mendapatkannya. Sedangkan untuk hambatan yang dihadapi oleh koordinator sekolah alam dalam mempersiapkan pembelajaran berbasis alam adalah kesulitan bertemu dengan teman-teman atau guru-guru untuk berdiskusi.

Berdasarkan hasil kesimpulan di atas, maka saran atau rekomendasi yang diajukan bagi: (1) Kepala SD Anak Saleh, hendaknya selalu memantau perkembangan pembelajaran peserta didik guna dijadikan sebagai pertimbangan dalam pengambilan keputusan terkait dengan pengelolaan sekolah dan pengembangan program pembelajaran berbasis masjid dan alam; (2) Guru SD Anak Saleh hendaknya selalu membuat alternatif kegiatan pembelajaran yang lain, dan menyisipkan sedikit nilai-nilai yang berkaitan dengan masjid atau alam untuk menunjang pembelajaran yang berbasis masjid ataupun alam; (3) Koordinator Keislaman hendaknya selalu membimbing dan membina anggota TTM agar dapat bekerjasama dalam mengelola pembelajaran berbasis masjid, mencoba memperbaiki cara berkoordinasi dengan guru ketika waktu pembelajaran berbenturan dengan kegiatan lain, dan mendata, menjadwal, atau mengatur penggunaan fasilitas yang terbatas; (4) Koordinator Sekolah Alam, hendaknya membuat jadwal tertentu untuk berdiskusi dengan guru-guru terkait penggunaan sekolah alam dan kebutuhan peralatan yang dibutuhkan; dan (5) Peneliti selanjutnya, hendaknya memperdalam pengetahuan 
mengenai perencanaan pembelajaran sehingga ketika berada di lapangan tidak merasa bingung, dan menyiapkan jadwal penelitian dengan matang sehingga penelitian bisa selesai tepat waktu.

\section{DAFTAR RUJUKAN}

Desilia, Ike Wahyu. 2014. Manajemen Pembelajaran Berbasis Alam Dalam Membentuk Karakter Peserta Didik. Skripsi. Universitas Negeri Malang.

Dimyati \& Mudjiono. 2009. Belajar dan Pembelajaran. Jakarta: PT Rineka Cipta.

Hanafy, Muh. Sain. 2014. Konsep Belajar dan Pembelajaran. (Journal Online). (journal.uin-alauddin.ac.id/index. php/lentera_pendidikan/article/viewFile/516/491), diakses pada tanggal 15 Februari 2019.

Mufidah, Hidayatul. 2015. Sistem Pembelajaran Matematika di Sekolah Alam. (Journal Online). (http://ejournal. kopertais4.or.id/pantura/index.php/qura/article/view/2049/1527), diakses pada tanggal 28 November 2018.

Peraturan Presiden Republik Indonesia Nomor 87 Tahun 2017 tentang Pendidikan Penguatan Karakter (PPK). (Online), (https://setkab.go.id/wp-content/uploads/2017/09/Perpres_Nomor_87_Tahun_2017.pdf), diakses pada tanggal 8 Mei 2019.

Rohman, Muhammad \& Amri, Sofan. 2015. Manajemen Pendidikan Analisis Dan Solusi Terhadap Kinerja Manajemen Kelas Dan Strategi Pengajaran Yang Efektif. Jakarta: PT. Prestasi Pustakaraya.

Santoso, Satmoko Budi. 2010. Sekolah Alternatif Mengapa Tidak?. Yogyakarta: Diva Press.

Setiyowati, Cici. 2016. Pengembangan Bahan Ajar Berbasis Sejarah Lokal Melalui Kajian Arsitektur Masjid Kuno Tawangsari Tulungagung Untuk Kelas XI IIS SMAN 1 Kedungwaru. Skripsi. Universitas Negeri Malang.

Siswanto. 2013. Pendidikan Karakter Berbasis Nilai-Nilai Religius. (Journal Online). (http://ejournal. stainpamekasan.ac.id/index.php/tadris/article/download/385/372), diakses pada tanggal 15 Januari 2019.

Sugiyono. 2012. Memahami Penelitian Kualitatif. Bandung : ALFABETA.

Triwiyanto, Teguh. 2015. Manajemen Kurikulum dan Pembelajaran. Jakarta: Bumi Aksara.

Ulfatin, Nurul. 2015. Metode Penelitian Kualitatif di Bidang Pendidikan:Teori dan Aplikasinya. Malang: Media Nusa Creative.

Usman, Husaini. 2014. Manajemen Teori, Praktik, dan Riset Pendidikan. Jakarta: Bumi Aksara.

Zubaedi. 2011. Desain Pendidikan Karakter, Konsepsi, dan Aplikasinya dalam Lembaga Pendidikan. Jakarta: Kencana. 